\title{
Potential of semi-structural and non-structural adaptation strategies to reduce future flood risk: case study for the Meuse
}

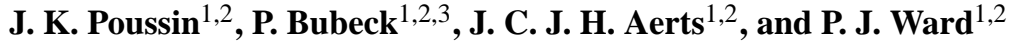 \\ ${ }^{1}$ Institute for Environmental Studies (IVM), VU University Amsterdam, Amsterdam, The Netherlands \\ ${ }^{2}$ Amsterdam Global Change Institute (AGCI), VU University Amsterdam, Amsterdam, The Netherlands \\ ${ }^{3}$ Helmholtz Centre Potsdam, German Research Centre for Geosciences (GFZ), Section Hydrology, Germany
}

Correspondence to: J. K. Poussin (jennifer.poussin@vu.nl)

Received: 26 June 2012 - Revised: 11 October 2012 - Accepted: 15 October 2012 - Published: 21 November 2012

\begin{abstract}
Flood risk throughout Europe has increased in the last few decades, and is projected to increase further owing to continued development in flood-prone areas and climate change. In recent years, studies have shown that adequate undertaking of semi-structural and non-structural measures can considerably decrease the costs of floods for households. However, there is little insight into how such measures can decrease the risk beyond the local level, now and in the future. To gain such insights, a modelling framework using the Damagescanner model with land-use and inundation maps for 2000 and 2030 was developed and applied to the Meuse river basin, in the region of Limburg, in the southeast of the Netherlands. The research suggests that annual flood risk may increase by up to $185 \%$ by 2030 compared with 2000 , as a result of combined land-use and climate changes. The independent contributions of climate change and land-use change to the simulated increase are $108 \%$ and $37 \%$, respectively. The risk-reduction capacity of the implementation of spatial zoning measures, which are meant to limit and regulate developments in flood-prone areas, is between $25 \%$ and $45 \%$. Mitigation factors applied to assess the potential impact of three mitigation strategies (dry-proofing, wet-proofing, and the combination of dry- and wet-proofing) in residential areas show that these strategies have a risk-reduction capacity of between $21 \%$ and $40 \%$, depending on their rate of implementation. Combining spatial zoning and mitigation measures could reduce the total increase in risk by up to $60 \%$. Policy implications of these results are discussed. They focus on the undertaking of effective mitigation measures, and possible ways to increase their implementation by households.
\end{abstract}

\section{Introduction}

In recent decades, flood damage throughout Europe has increased because of development in flood-prone areas (Barredo, 2009; Munich RE, 2010). Flood damage is projected to increase further as a result of continued urban development combined with climate-change effects on river discharges and flood probabilities (Aerts et al., 2006; Bouwer et al., 2006; IPCC, 2007; te Linde et al., 2010; Ward et al., 2012). In the light of these developments, more and more studies are assessing changes in flood risk, where flood risk is defined as the probability of flooding multiplied by the potential consequences, such as economic damage or loss of lives (Maaskant et al., 2009; Merz et al., 2010). Flood risk is a function of: (a) the hazard, (b) the exposure, and (c) the vulnerability (Crichton, 1999; Poussin et al., 2012). This definition is also used in major recent reports on risk and climatechange impacts (UNISDR, 2011; IPCC, 2012).

To manage current and future flood damage and risk, different adaptation strategies are available and have been studied. These strategies are diverse and include the use of technical measures to reduce the probability of flooding (e.g. Vis et al., 2003; Merz et al., 2010); the provision of flood protection such as storm surge barriers and dikes (Aerts and Droogers, 2004); the use of insurance to provide compensation, to help recovery, and provide incentives for damage mitigation (Kunreuther, 2006; Crichton, 2008; Paudel et al., 2012); the use of spatial zoning with increased control over land-use changes and developments of new and existing urban areas (Burby et al., 2000); and the use of damage reduction measures on houses, which are also called "mitigation measures" or flood-proofing measures (Kreibich et al., 2005; Kreibich and Thieken, 2009). 
Recent studies based on past floods and/or economic models have shown that adequate undertaking of flood-proofing measures can considerably decrease the costs of floods for households. These studies focus on avoided costs, damage reduction, and/or cost-benefit ratios. Wind et al. (1999) focus on the potential link between household preparedness and the $35 \%$ decrease of the losses between the floods of 1993 and 1995 on the Meuse. ICPR (2002) provide ranges of damage reduction percentages for different flood damage mitigation measures. Kreibich et al. (2005) and Kreibich and Thieken (2009) provide data on the effectiveness of household flood-proofing measures in reducing flood damages in Dresden, Germany. ABI (2003) reports on the costeffectiveness of 34 (mostly) semi-structural measures, for 5 different types of houses from semi-detached properties to bungalows, and 3 floodwater heights. Thurston et al. (2008) and Kreibich et al. $(2011,2012)$ are two studies focusing on the cost-benefit ratios of semi-structural flood-proofing measures and their relation with the probability of flooding. Despite these studies, there is still little insight into how semistructural and non-structural measures can decrease the flood risk beyond the local level, now and in the future.

The main aims of this study are, therefore: (a) to assess the sensitivity of riverine flood risk to changes in land use and climate; and (b) to examine the potential of different adaptation strategies at the regional scale to reduce future flood damage and risk. The study is carried out for the casestudy region of the Meuse river in the province of Limburg, in the southeast of the Netherlands. This assessment is the first study of this kind carried out in the Netherlands. Flood risk is assessed by using simulated damage results for multiple return periods in order to calculate the expected annual damage (EAD), which is estimated by integrating the area under an exceedance probability loss curve (i.e. risk curve) (Grossi and Kunreuther, 2005).

An inundation model called the Floodscanner model (Ward et al., 2011a) is coupled with a damage model called the Damagescanner model (Klijn et al., 2007; Aerts et al., 2008) to simulate damage and flood risk for the current situation and for future scenarios of land-use and climate change, with and without adaptation strategies at the regional scale. Adaptation strategies include spatial zoning measures and three types of flood-proofing measures: namely, dryproofing, wet-proofing, and a combination of dry- and wetproofing measures. The damage- and risk-reduction capacity of the adaptation strategies is assessed by using relative changes, since research shows that estimates of relative changes in flood damage are more robust than estimates of absolute changes (Bubeck et al., 2011).

The remainder of the article is divided as follows. Section 2 describes the case-study area. Section 3 describes the data and methods used. It includes a short description of the model and adaptation strategies. Section 4 describes the results of the damage and risk calculations, with and without adaptation strategies. It ends with an analysis of the geographical distribution of the risk and the effectiveness of the mitigation measures. Section 5 discusses the results, and conclusions are presented in Sect. 6.

\section{Case study: the Meuse in Limburg}

\subsection{The Meuse}

The Meuse is a predominantly rain-fed river, with a length of about $875 \mathrm{~km}$ from its source in France to its mouth in the Netherlands. Its catchment area extends over parts of Belgium, France, Germany, Luxembourg, and the Netherlands, over an area of about $33000 \mathrm{~km}^{2}$. The Meuse basin is one of the most densely-populated areas of Western Europe, and is inhabited by about 9 million people. The river itself is navigable, and provides drinking water for about 6 million inhabitants (De Wit et al., 2007).

Mean annual precipitation over the basin is reasonably evenly distributed throughout the year. The Meuse has a relatively rapid response to rainfall, and is relatively sensitive to floods (van Pelt et al., 2009), with flood waves mainly occurring during the winter half-year. The section of the Meuse studied in this research flows between the border of Belgium and the Netherlands (upstream) to river kilometre 166 (downstream) near the village of Mook (Fig. 1). Along this section, the Meuse forms a natural border between Belgium and the Netherlands. During floods the river can therefore flood on both the Dutch and the Belgian side. In this study, we examine inundation, flood damage, and flood risk, only in the Dutch part. The Limburg Meuse occupies a terraced river valley (Van der Meulen et al., 2006). Unembanked sections can be inundated if river levels rise above the level of the bank. There are also several (relatively small) dike-ring areas along this section of the Meuse. Dike-rings are separate administrative units that are designed to withstand floods up to certain return periods (such as $250 \mathrm{yr}$ in the dike-rings along the Meuse in Limburg), in order to provide a certain level of protection against floods within the dike-ring areas (Poussin et al., 2010).

\subsection{Past research on flood risk in the Meuse basin}

Since the severe floods along the Meuse in 1993 and 1995, several studies have been conducted to analyse the past, present, and future hydrological behaviour of the river Meuse and the effects of climate and land-use changes on it (Bates and De Roo, 2000; De Wit et al., 2001, 2006, 2007; Jacquet et al., 2003; Pfister et al., 2004; Booij, 2005; Aerts et al., 2006; Tu, 2006; Ward et al., 2007, 2008, 2009, 2011b; De Wit, 2008; Leander et al., 2008; Ward, 2008); past flood damage (Loche, 1994; Van Meijgaard and Jilderda, 1996; Wind et al., 1999), and flood risk (Ward et al., 2011a). The results of hydrological models for the future generally project that mean winter-season discharge in the future will be greater 


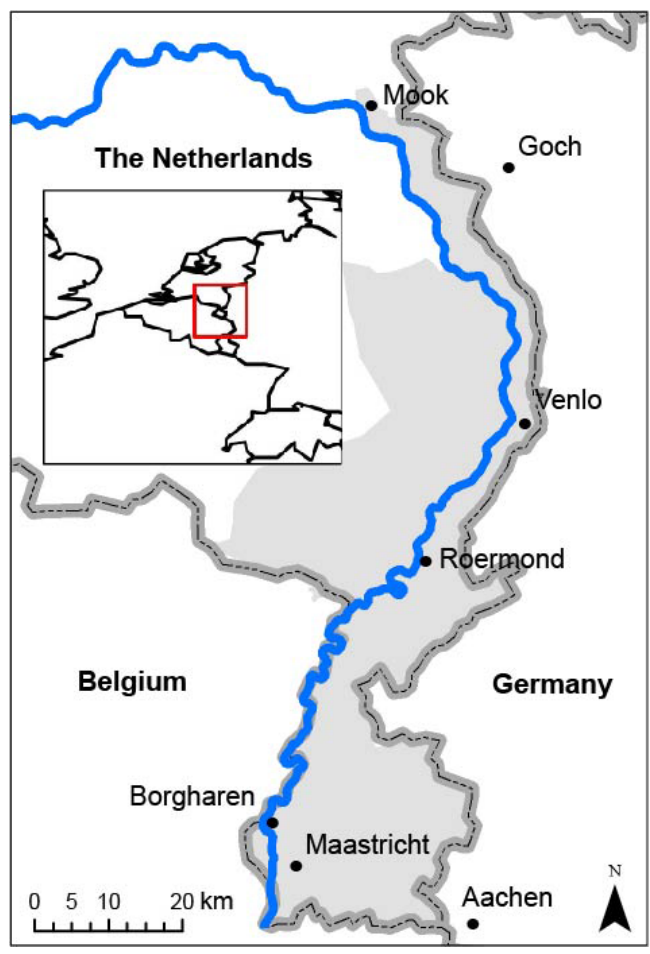

Fig. 1. Map of the Meuse in Limburg.

than it was in the past, and the frequency of floods will increase.

The case-study area for this research was chosen for two reasons. First, relatively good data are available for setting up both the inundation and damage models. Second, while the area is relatively prone to flooding compared with the downstream sections of the Meuse where safety standards are considerably higher, it has received less attention in recent studies on flood risk in the Netherlands. Risk estimates have been made for large Dutch dike-ring areas downstream of Mook in three major projects: Floris (Ministry of Transport, Public Works and Water Management, 2005), Nederland Later (Klijn et al., 2007), and Attention to Safety (Aerts and Botzen, 2011). Other recent publications have also investigated flood risk in those downstream dike-rings (e.g. Bouwer et al., 2009, 2010; De Moel et al., 2011).

Fewer studies have examined the upstream area of the Meuse in which we are conducting our research. Ernst et al. (2010) assessed high-resolution economic damage $(2 \mathrm{~m} \times 2 \mathrm{~m})$ along two sections of the river Ourthe, a tributary of the Meuse in Belgium. Wind et al. (1999) reported observed (direct) damage in Dutch Limburg for the flood events of 1993 and 1995 of about $€ 149$ million (1993) and $€ 91$ million (1995) ${ }^{1}$ (in year 2000 euros). Van der Sande et

1 The original values (in Dutch guilders) were converted to euros ( 1 euro $=2.20371$ Dutch guilders), and updated from 1993 and 1995 values to 2000 values, using GDP multipliers derived from Statistics Netherlands (www.cbs.nl). al. (2003) simulated direct damage in the villages of Itteren and Borgharen in Dutch Limburg, and estimated property damage to be about $€ 82$ million (in year 2000 euros) for the 1995 Meuse flood. Ward et al. (2011a) studied the impact of the selection of inundation return periods on simulated flood risk. They showed that the simulated risk is highly sensitive to the selection of return periods used to derive the risk curve, ranging from $€ 23$ million per year up to $€ 111$ million per year, under the assumptions used in that study.

\section{Data and methods}

An overview of the methods, models, and data used is shown in Fig. 2. For this research, flood risk is quantified as the expected annual damage (EAD). It is assessed by combining the damage results for different exceedance probabilities, and integrating the area under an exceedance probability loss curve (i.e. risk curve).

To assess the flood damage at different return periods, the Damagescanner model is used in combination with two types of scenarios: climate scenarios and land-use scenarios. Landuse maps for 2000 and 2030 are used to represent the respective exposure. Inundation maps for nine different return periods, for climate 2000 and future climate 2030, are used to represent the hazard. Stage-damage functions represent the vulnerability by providing a relationship between inundation height, land use, and damage. To assess the potential impact of spatial zoning measures, the 2030 land-use maps are modified according to a spatial zoning project conducted in Limburg (see Sect. 3.3 "Adaptation strategies"). To assess the impact of the mitigation measures in residential areas, mitigation factors are applied to the stage-damage functions. Since research shows that there are high uncertainties associated with estimates of absolute changes in flood damage, and that estimates of relative changes are more robust (Bubeck et al., 2011), the damage and risk increases, as well as the damage- and risk-reduction capacity of the adaptation strategies, are assessed using relative changes.

\subsection{Inundation modelling: Floodscanner and climate-change scenarios}

To generate the inundation maps used for this research, an inundation model is used that was developed for a previous study on the Meuse, the Floodscanner model (Ward et al., 2011a). The model uses a simple zero-dimensional planarbased approach, conceptually similar to that of Priestnall et al. (2000). This allows for the rapid simulation of the large number of inundation maps required in this study. Since the model is not hydrodynamic, it is assumed that upstream flooding does not lead to a reduction in discharge downstream, leading to an overestimation of downstream inundation depths. However, Ward et al. (2011a) previously carried out a validation of Floodscanner for the Meuse river in Dutch 

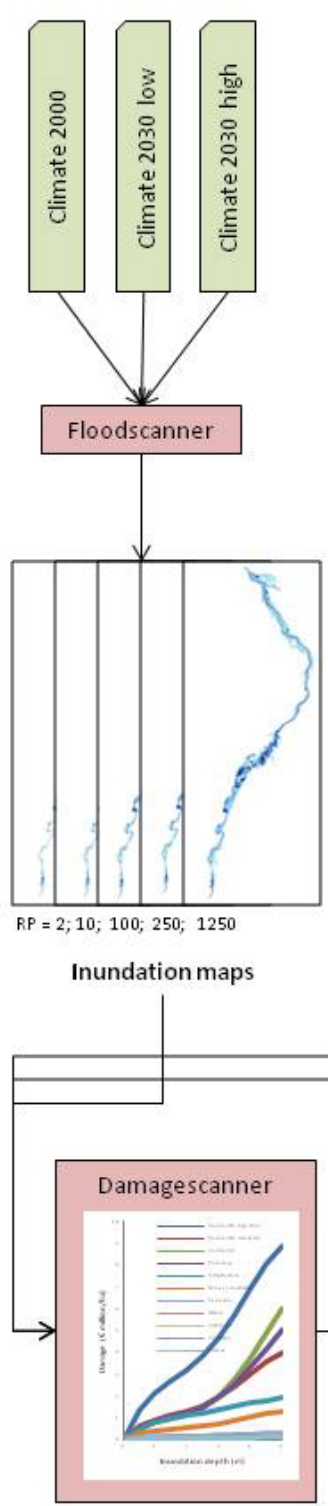
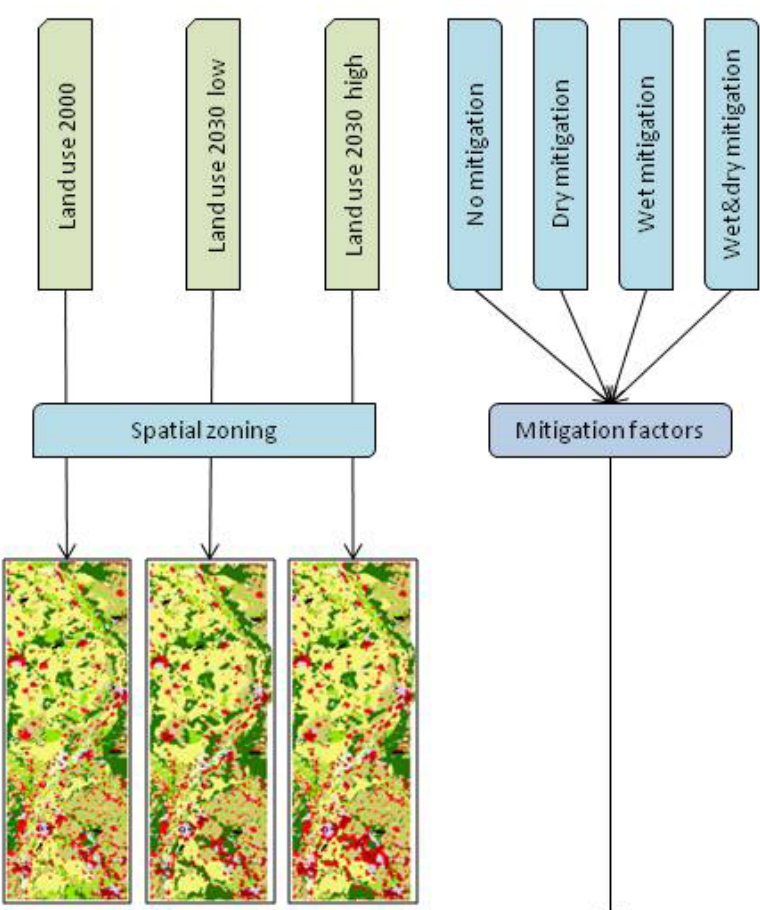

Mitigationfactors

Land use maps (per land use category)

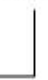

Risk \& Risk maps

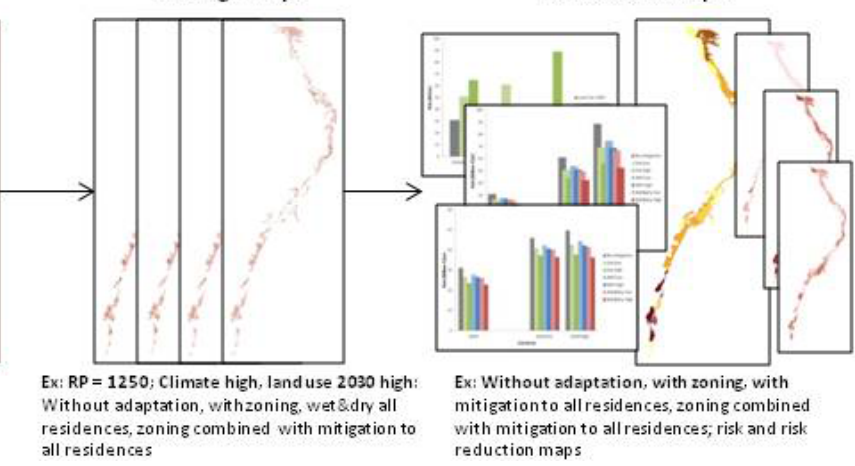

Fig. 2. Flow chart of the methods, models, and data used, with climate and land-use scenarios, and stage-damage functions. The Floodscanner produces the inundations maps. The Damagescanner calculates the damage and produces the damage maps used to assess the risk. Adaptation strategies include damage mitigation measures and spatial zoning. The flood risk is calculated as the area under an exceedance probabilitydamage curve (i.e. risk curve).

Limburg, and found that it performed well compared with images of the historical floods of 1993 and 1995, as well as compared with results from a process-based 2-D hydrodynamic model (WAQUA, provided by Rijkswaterstaat Dienst Limburg). The maps in Fig. 3 show the few locations which did not perform as well. For example, the modelled maps show an inundation area at the confluence of the Niers tributary and the Meuse (shown by circle a in Fig. 3). Here, the simplified inundation model has difficulty in dealing with hydraulically complicated backwater effects. A second source of anomalies is around several of the new "Maasplassen"; these lakes were created by sand and gravel mining, and some were completed post-1995 (for example the Lange Vlieter, shown by circle b in Fig. 3). Hence, these lakes are "inundated" in the model, but were not inundated in 1993 and 1995 because at that time the gravel and sands had not been extracted.

The model is raster-based with a spatial resolution of $50 \mathrm{~m} \times 50 \mathrm{~m}$. It uses stage-discharge relationships to estimate the water level for different discharges, and creates a 


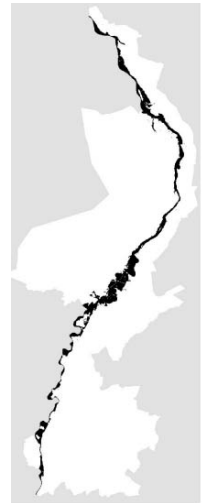

Observed - 1993

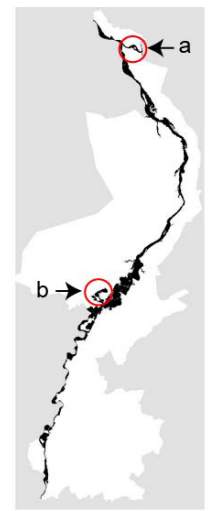

Modelled - 1993

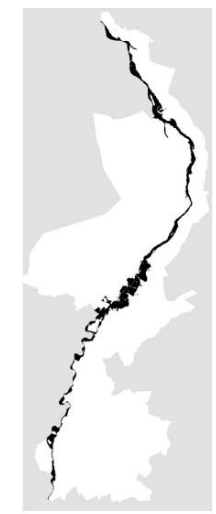

Observed - 1995

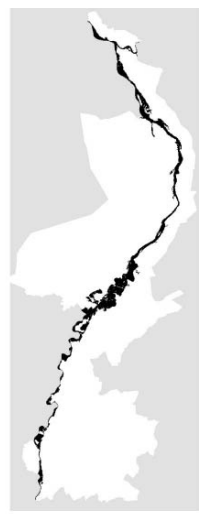

Modelled - 1995
Fig. 3. Inundation extent maps based on aerial photography and satellite imagery (observed) and Floodscanner (modelled) for the floods of 1993 and 1995. The red circles show two locations at which the model did not perform well (a: confluence of the Niers and the Meuse rivers; b: the lake known as the Lange Vlieter, completed post-1995) (adapted from Ward et al., 2011a).

planar surface representing the water surface. Using a digital elevation model (DEM), the inundation depth is deduced from the difference between the water level and the elevation. Several steps are required to: (a) derive the river network raster, (b) develop stage-discharge relationships, (c) simulate the planar water level surface, and (d) estimate flood inundation depth:

1. Derive the river network raster: We developed the river network raster based on a DEM derived from elevation data used in the WAQUA model of the Meuse. These data were provided by Rijkswaterstaat Limburg (RWS Limburg), as a triangulated irregular network (TIN) map (WAQUA version 2005-02, configuration J09 4). We rasterised these data to a spatial resolution of $50 \mathrm{~m} \times 50 \mathrm{~m}$. For areas outside the WAQUA configuration, we used the AHN5 (Actueel Hoogtebestand Nederland) DEM, which covers the Netherlands at a resolution of $5 \mathrm{~m} \times 5 \mathrm{~m}$. Again, this DEM was resampled to a resolution of $50 \mathrm{~m} \times 50 \mathrm{~m}$.

2. Develop stage-discharge relationships: We used stagedischarge data from the Meuse WAQUA schematisation J09 4, supplied by RWS Limburg. The rating curves give stage height at each river kilometre for discharges of different return periods (up to $1250 \mathrm{yr}$ ) at St. Pieter (upstream, near the Belgian-Dutch border), i.e. the downstream stages refer to specific return periods upstream. The stage heights downstream account for lateral discharges from side rivers, the main one being the Roer.

3. Simulate planar water level surface: Discharge at Borgharen (upstream) is given to the model as input.
The model then estimates a corresponding water level at each river cell based on the stage-discharge relationships described above. All grid-cells in the study area are assigned to their nearest river kilometre grid-cell based on the Euclidean distance, leading to a theoretical planar water-level surface.

4. Estimate flood inundation depth: The elevation of each cell is subtracted from the planar water level surface, to give an inundation depth per grid-cell. Inundated cells not connected to the river via a flow-path with direct connectivity are removed. Furthermore, there are about 40 small dike-rings in the case-study area that provide protection against floods with return periods up to $250 \mathrm{yr}$. These dike-rings are therefore not allowed to flood at discharges lower than the $250 \mathrm{yr}$ return period value (for each scenario).

Floodscanner is then used to simulate inundation levels for all return periods from 2 to $1250 \mathrm{yr}$ (i.e. 1249 return periods in total), based on the current climate data. The discharge magnitudes corresponding to each return period are derived using a generalised extreme value (GEV) distribution, fitted on discharge time-series for the period 1961-1990 simulated using the HBV model, and reported in full in Drogue et al. (2010). However, in most practical applications, it would be impractical and too time-consuming to compile this number of inundation maps to carry out flood risk assessment, and therefore it was decided to select a smaller number of inundation maps for our further analyses. Ward et al. (2011a) showed that the selection of the return periods used to calculate the risk, or EAD, has a large influence on the final risk estimate. Hence, we first calculated the risk based on all of the inundation maps, which resulted in a flood risk estimate of $€ 34$ million per year. We then selected the combination of nine inundation maps that gave the estimate of risk that was closest to the latter estimate. This resulted in the selection of inundation maps for return periods of $2,5,10,20,50,100$, 250,251 , and $1250 \mathrm{yr}$; for this combination of return periods, the calculated risk is $€ 31$ million per year. The $251 \mathrm{yr}$ map represents the inundation at which dikes in Limburg are assumed to fail. The $1250 \mathrm{yr}$ map corresponds to the protection level for dike-rings in the Netherlands downstream from Limburg, and is an important return period in Dutch water management (Bouwer et al., 2010).

To assess the impact of climate change on the damage and the risk, two climate-change scenarios are used: the scenarios $\mathrm{G}$ and $\mathrm{W}+$ for the Netherlands, which are based on the Intergovernmental Panel on Climate Change scenarios (IPCC, 2000). Scenario $G$ corresponds to an increase in temperature by 2050 of about $1{ }^{\circ} \mathrm{C}$, while scenario $\mathrm{W}+$ corresponds to an increase by 2050 of $2.3^{\circ} \mathrm{C}$ to $2.8^{\circ} \mathrm{C}$ (Van den Hurk et al., 2006). Since the $\mathrm{G}$ scenario assumes a lower level of climate change than the $\mathrm{W}+$ scenario, in this paper we refer to them as "climate low" and "climate high", respectively. 
Table 1. Simulated discharge at Borgharen corresponding to the different return periods used in this study for the 2000 climate scenario, and the 2030 low and high climate scenarios.

\begin{tabular}{lrrr}
\hline \multirow{2}{*}{$\begin{array}{l}\text { Return } \\
\text { period }\end{array}$} & \multicolumn{3}{c}{ Discharge $\left(\mathrm{m}^{3} \mathrm{~s}^{-1}\right)$} \\
\cline { 2 - 4 } & 2000 & 2030 low & 2030 high \\
\hline 2 & 1589 & 1693 & 1716 \\
5 & 1885 & 1957 & 2013 \\
10 & 2112 & 2197 & 2278 \\
20 & 2328 & 2453 & 2560 \\
50 & 2720 & 2831 & 2950 \\
100 & 2960 & 3072 & 3207 \\
250 & 3258 & 3372 & 3523 \\
251 & 3259 & 3373 & 3525 \\
1250 & 3814 & 3933 & 4120 \\
\hline
\end{tabular}

The discharge magnitudes corresponding to each return period for each scenario are again derived using a generalised extreme value (GEV) distribution, fitted on discharge timeseries for the period 2021-2050 simulated using the HBV model (Drogue et al., 2010). The simulated discharge at Borgharen corresponding to each of the return periods used in this study and the three climate scenarios (2000, 2030 low, and 2030 high) are shown in Table 1.

\subsection{Damage modelling}

\subsubsection{Damagescanner}

The damage calculations are conducted using the Damagescanner model. The Damagescanner has been used in a number of studies on the Rhine and the Meuse (Klijn et al., 2007; Bouwer et al., 2009, 2010; Aerts and Botzen, 2011; De Moel et al., 2011; Te Linde et al., 2011; Ward et al., 2011a). The model is used to calculate flood damage, from which the flood risk results are derived. It needs two inputs: an inundation map to represent the hazard and a land-use map to represent the exposure. In the model, stage-damage functions (SDFs) are used for each land-use category to provide the relation between the inundation depth, the land-use type in each grid-cell, and the damage. Each land-use category has its own stage-damage function.

\subsubsection{Land-use maps}

To represent the evolution of land use in Limburg from the year 2000 to the year 2030, three maps are used: a reclassified CORINE Land Cover land-use map for 2000, and land-use maps for 2030 under two scenarios which were created using the Land Use Scanner (Loonen and Koomen, 2009). The Land Use Scanner simulations used in this study were developed for the Rhine and Meuse basins, and are described in greater detail in Te Linde et al. (2011). Each map represents the allocation of 13 land uses in Limburg, from residential areas of high and low density, to commercial, infrastructure, mines, recreation, nature, agriculture, cultivation, pasture, and inland water.

The future land-use maps are based on two future socioeconomic scenarios, the "Global Economy" (GE) scenario and the "Regional Communities" (RC) scenario, which are, respectively, comparable to the $\mathrm{A} 1$ and $\mathrm{B} 2$ scenarios developed by the IPCC (IPCC, 2000). The Global Economy scenario is based on high economic and population growth. The land-use map, referred to in this study as "land use 2030 high", shows a large increase in urban areas. The Regional Communities scenario is based on a low economic and population growth, a regional focus, and strict environmental regulations, including a restriction of new urban developments in the $100 \mathrm{yr}$ flood-zone. This scenario results in a land-use map, referred to as "land use 2030 low", which shows a lower increase in urban areas. The land-use maps have a spatial resolution of $50 \mathrm{~m} \times 50 \mathrm{~m}$.

These land-use maps are based on simulations of landuse change resulting from projected socio-economic development, and, while spatial regulations are included via the economic scenarios, specific local and regional spatial planning measures and restrictions are not yet included. Hence, in some areas Land Use Scanner may simulate urban development, whilst in reality this may be an area in which such development is not allowed under local or regional spatial planning regulations.

In order to assess different scenarios of damage and risk in 2030, in this study we linked the climate scenario G with the future land-use scenario of 2030RC, and the climate scenario $\mathrm{W}+$ with the future land-use scenario of 2030GE (see Sect. 3.2.2 "Land-use maps") (see also Bouwer et al., 2010).

\subsection{Adaptation strategies}

In order to assess the effects of adaptation strategies on the damage and the risk, we assess the effectiveness of several spatial zoning and mitigation measures using the Damagescanner model. The spatial zoning measures are used to modify the land-use maps. These measures, and their implementation in Damagescanner, are described below.

\subsubsection{Spatial zoning}

In the Province of Limburg, a spatial zoning project is currently being carried out in accordance with the "Beleidslijn Grote Rivieren (BGR)" and the "Beleidsregels", respectively a Dutch law and the corresponding rules that are meant to limit and regulate developments in Dutch flood-prone areas $^{2}$. The Rijkwaterstaat (RWS) Limburg provided GIS maps showing areas where either: (0) there are no restrictions, (1) new buildings and developments are not allowed, except

2 BGR zoning by the RWS Limburg, last accessed on 28 March 2012: www.rijksoverheid.nl/documenten-en-publicaties/ kamerstukken/2006/07/26/beleidslijn-grote-rivieren.html. 
if they are river-bound (e.g. harbour), and (2) new buildings and developments are allowed under certain conditions such as compensating for the loss of volume of water.

To assess the effect of the spatial zoning measures shown in these maps on flood risk in Limburg, we adapted the landuse maps for 2030 (simulated using Land Use Scanner) to reflect the information contained in the BGR zoning maps. As such, areas in the BGR zoning maps that are planned to remain as they are now in the future (e.g. nature or agricultural fields), are sometimes projected to undergo new urban developments in the Land Use Scanner model. Hence, we modified these areas in the 2030 land-use maps by removing the new urban developments and replacing them with the land use from the 2000 land-use map. With this spatial zoning measure, we assume that although the demand for urban development remains, that demand will be built outside of the flood-prone area since new buildings within it are not allowed.

\subsubsection{Flood damage mitigation measures}

To estimate the effectiveness of flood-damage mitigation measures on risk in residential areas, we investigated three mitigation strategies in Damagescanner, namely: (a) dryproofing, (b) wet-proofing, and (c) the combination of dryand wet-proofing. To implement these measures in Damagescanner, we developed damage reduction factors (0-1) to represent the proportion of damage that could be avoided at each inundation depth if the strategies were applied. These damage reduction factors are used to adjust the original SDFs in Damagescanner. The factors are based on a literature review, and are described in this section. For each strategy, we developed two sets of reduction factors to represent a low and a high range of effectiveness.

1. The dry-proofing strategy includes measures such as the use of sandbags, coffer dams, or panels on doors and windows to stop the flood waters from entering. According to the ICPR report (2002), such measures can decrease damage, if a flood occurs, by between $60 \%$ and $100 \%$. Research shows that these measures are most effective up to $1 \mathrm{~m}$ of water height, because above $1 \mathrm{~m}$ the chance of wall failure due to water pressure increases (ICPR, 2002; EA, 2003; Boulet-Desbareau et al., 2005). The reduction factors chosen for this research are therefore $60 \%$ reduction of damage per house up to $1 \mathrm{~m}$ of water for the low range, and $100 \%$ reduction of damage per house up to $1 \mathrm{~m}$ of water for the high range. Above $1 \mathrm{~m}$ of water, it is considered that the reduction of damage is $0 \%$.

2. The wet-proofing strategy includes all the measures, semi-structural and non-structural, that can be taken to adapt the exterior, interior, and uses of a house, in order to decrease the damage if flood waters enter the house. It includes measures such as the strengthening of walls against water pressure, adapting the flood-prone parts of the house with waterproof materials, not keeping non-waterproof objects and furniture in flood-prone parts of house, moving vulnerable appliances to upper floors, installing one-way valves on water evacuation pipes to stop the waters from entering the house via the pipes, and storing paints and chemicals in the upper parts of the home. The ICPR report (2002) shows that such measures can reduce damage to house contents by up to $40 \%$, while according to Kreibich et al. (2005), these flood damage mitigation measures can reduce damage to buildings by between $36 \%$ and $53 \%$, and to household contents by between $48 \%$ and $53 \%$. The reduction factors chosen for our research are $35 \%$ damage reduction up to $2 \mathrm{~m}$ for the low range, and $50 \%$ damage reduction up to $2 \mathrm{~m}$ for the high range. Above $2 \mathrm{~m}$ of water, previous studies have indicated that the damage-reducing capacity of wet-proofing measures strongly decreases (ICPR, 2002; ABI, 2003; Kreibich and Thieken, 2009). At such water levels, we therefore consider that there is no reduction of damage, and hence the reduction factor is $0 \%$.

3. The third strategy examined in this study combines the dry-proofing strategy and the wet-proofing strategy, hereafter referred to as the "wet\&dry-proofing strategy". For this strategy, we consider that a house can be protected by both wet and dry proofing, i.e. by preventing the waters from entering the house as much as possible, while also adapting the house to decrease the damage in case waters enter. The reduction factors for the low range are equal, for each corresponding height, to the lowest factors of the dry-proofing strategy up to $1 \mathrm{~m}$ $(60 \%)$, and the wet-proofing strategy up to $2 \mathrm{~m}(35 \%)$. For the high range, the reduction factors are equal to the highest factor of the dry-proofing strategy up to $1 \mathrm{~m}$ $(100 \%)$ and wet-proofing strategy up to $2 \mathrm{~m}(50 \%)$. Above $2 \mathrm{~m}$ of water the reduction factor is $0 \%$.

In a first step, these factors are applied to the residential high-density and residential low-density land uses, as if all houses, i.e. both existing and new buildings, are protected by the measures. Though such wide implementation of the strategies is probably not feasible in practice, this calculation provides a maximum potential risk reduction that could be reached when applying the flood-proofing measures used in this study. In a second step, the mitigation factors are applied only to all the new residential areas in 2030, i.e. those areas that are classified as residential in the Land Use Scanner results for 2030 but are not residential in the land-use map of 2000. Hence, in this second step, the mitigation strategies are not applied to existing buildings, but only to all newly built houses until 2030. This simplification assumes that all new buildings would be flood-proofed, which is possibly more feasible than flood-proofing all existing and new buildings. 
Table 2. Increase in EAD (risk) (in percentages), for the future scenarios (climate and/or land use) for 2030 compared with the 2000 scenario.

\begin{tabular}{lrrr}
\hline \multirow{2}{*}{ Land use } & \multicolumn{3}{c}{$\%$ Risk increase } \\
\cline { 2 - 4 } & Climate 2000 & Climate low & Climate high \\
\hline 2000 & N/A & 20 & 37 \\
2030 low & 64 & 97 & N/A \\
2030 high & 108 & N/A & 185 \\
\hline
\end{tabular}

This step therefore seems interesting to obtain (slightly) more realistic risk reduction results.

\section{Damage and risk results}

In this section, we describe the results of the risk calculations, with and without adaptation strategies. We refer to the following scenarios: 2000 scenario (i.e. climate 2000 combined with land use 2000), 2030 low scenario (i.e. climate 2030 low combined with land use 2030 low), and 2030 high scenario (i.e. climate 2030 high combined with land use 2030 high).

\subsection{Flood-risk estimates without adaptation strategies}

The relative percentage changes in risk between the 2000 scenario and the future scenarios with land-use and/or climate change, without mitigation or spatial zoning measures, are shown in Table 2.

The simulated risk in the 2000 scenario is ca. $€ 31$ million per year. Compared with this scenario, the future scenarios show a risk increase of $97 \%$ for the 2030 low scenario and $185 \%$ for the 2030 high scenario (Table 2). The relative influence of land-use change on these increases is greater than that of climate change. The impacts of land-use change alone are increases in risk of $64 \%$ and $108 \%$ for the 2030 low and 2030 high scenarios, respectively, whilst the impacts of climate change alone are increases in risk of $20 \%$ and $37 \%$ (again for the 2030 low and high scenarios, respectively).

Figure 4 shows the damage results, plotted on a risk curve, for the different climate and land-use scenarios, without adaptation strategies. The impact of dike failure for a return period of $251 \mathrm{yr}$ or more (i.e. exceedance probability lower than 0.004), which is above the current safety standard of the dikes, is clearly visible in the figure, with much lower values for flood damage below this return period.

The relative increase in flood damage (in percentages) for different exceedance probabilities and future scenarios compared with the 2000 scenario is shown in Fig. 5. The figure shows that, except for high probabilities, the simulated increases in damage as a result of land-use change only are greater than those for climate change only. According to our results, in relative terms the combined impact of

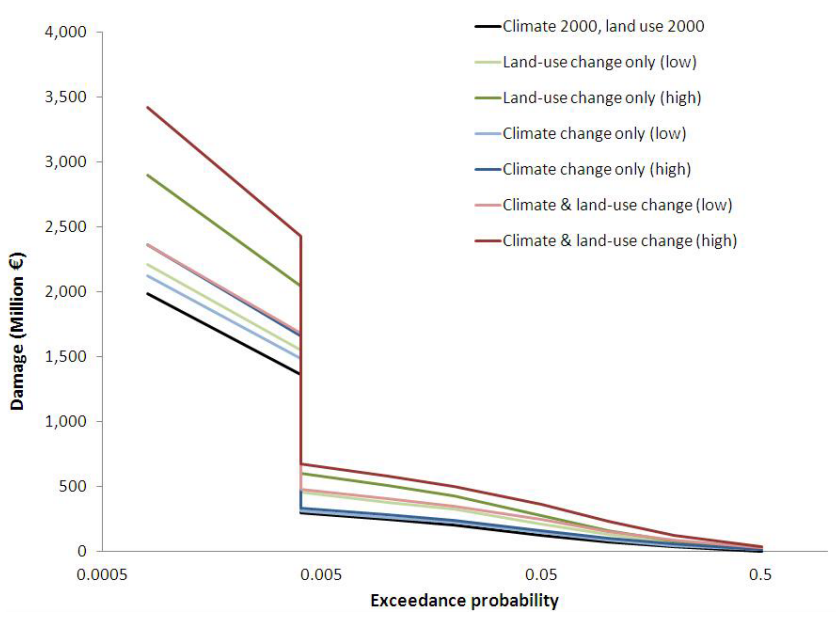

Fig. 4. Damage results for the different climate and land-use scenarios, and for different exceedance probabilities, without adaptation strategies (exceedance probabilities on a log scale).

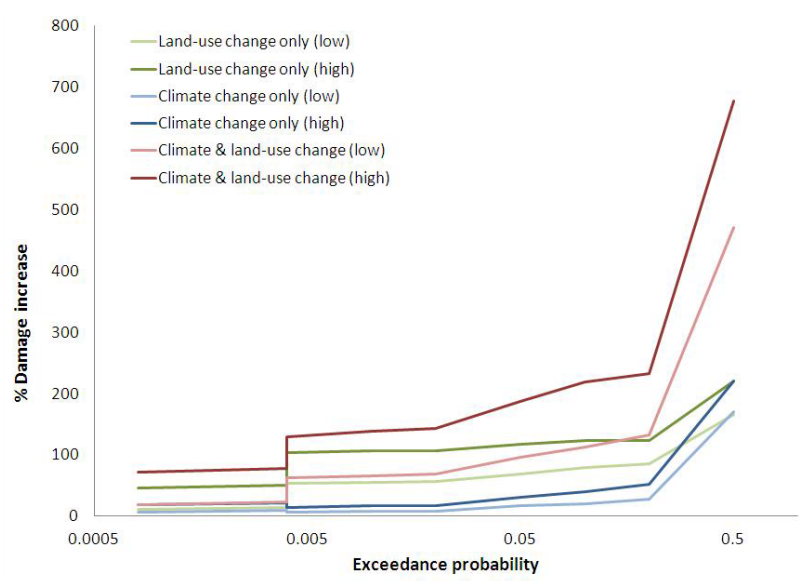

Fig. 5. Increases in damage (\%) compared with the 2000 scenario for the future climate and land-use scenarios, without adaptation strategies (exceedance probabilities are on a log scale).

land-use change and climate change on damage is greater for floods with higher probabilities, although in absolute terms the damage increase is smaller than it is for low probability floods.

\subsection{Risk-reducing capacity of spatial zoning measures}

Table 3 shows the results when the land-use maps for 2030 are adjusted to include the BGR zoning currently implemented in Limburg. We see that the impact of the land-use change on the risk (and therefore the total risk increase in 2030) is much lower when the BGR zoning is included. Compared with the 2000 scenario, land-use change alone now leads to an increase in risk of $23 \%$ for the 2030 low scenario, and $17 \%$ for the 2030 high scenario. Compared with the 2000 scenario, the 2030 low and 2030 high scenarios 
Table 3. Increase in risk (\%) compared with the 2000 scenario for low and high climate and land-use scenarios, including BGR zoning. In brackets: risk-reduction capacity (\%) of the BGR zoning, where the risk results with zoning are compared with the risk results without zoning, for the same scenarios.

\begin{tabular}{lrrr}
\hline \multirow{2}{*}{ Land use } & \multicolumn{3}{c}{ \% Risk increase } \\
& \multicolumn{3}{c}{ (\% Risk reduction of BGR zoning) } \\
\cline { 2 - 4 } & Climate 2000 & Climate low & Climate high \\
\hline 2000 & N/A & $20(0)$ & $37(0)$ \\
2030 low & $23(25)$ & $48(25)$ & N/A \\
2030 high & $17(45)$ & N/A & $60(44)$ \\
\hline
\end{tabular}

would lead to an increase in risk of $48 \%$ and $60 \%$, respectively. The values in brackets show the risk reduction of the BGR zoning when the results are compared with the risk without zoning for the same scenario (for instance, the risk for the 2030 low scenario with zoning is compared with the risk for the 2030 low scenario without zoning). We refer to these risk-reduction results as the risk-reduction capacity of the measures. In this case, the BGR zoning alone would decrease the risk by $25 \%$ for the low scenarios, and by up to $45 \%$ for the high scenarios.

The results in Table 3 show that the increase in risk between the 2000 scenario and the 2030 low scenario is almost equally due to the changes in land use and climate. However, the same is not the case for the increase in risk between the 2000 scenario and the 2030 high scenario. In the latter case, the relative impact of climate change is now higher than that of land-use change. Moreover, if we only consider changes in land use (assuming a constant climate 2000 scenario), the results show a greater increase in risk between 2000 and 2030 for the low land-use scenario (23\%) compared with the high land-use scenario (17\%). This is due to the BGR zoning, which lowered the differences between the low and high future land-use scenarios by countering the land-use evolutions projected by the Land Use Scanner.

\subsection{Risk-reducing capacity of mitigation measures}

\subsubsection{Mitigation factors applied to all residential areas}

The mitigation factors used to evaluate the damage- and riskreduction capacity of mitigation measures correspond to the potential damage reduction for one protected house. To examine the maximum risk-reduction capacity of such measures, these factors are, in a first step, applied to all highdensity and low-density residential land uses.

Figure 6 provides the flood risk estimates, in million euros, for the different mitigation strategies. The simulated risk for the 2000 scenario is $€ 31$ million per year. Again, note that the absolute estimates are subject to high uncertainty, but the relative changes between the 2000 and future scenarios give an indication of the order of magnitude of the change that can

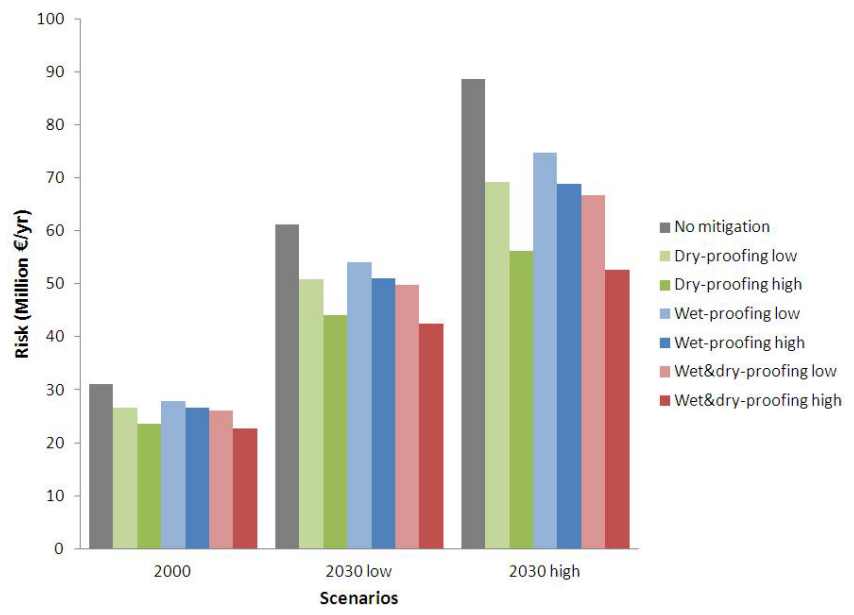

Fig. 6. Flood risk estimates (expressed in terms of EAD) for the 2000 scenario and the 2030 low and high scenarios (in million euros per year) for different mitigation strategies applied to all residential areas.

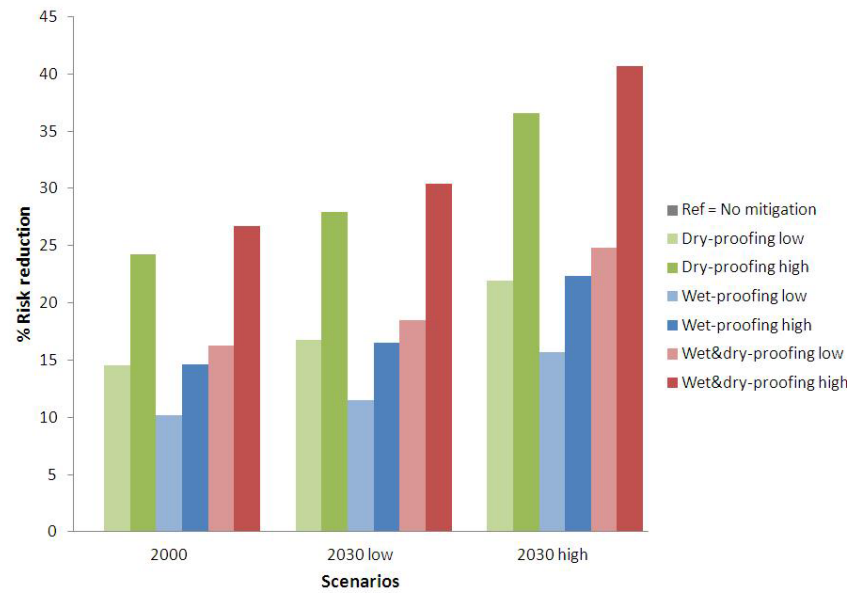

Fig. 7. Risk-reduction capacity (\%) of the mitigation strategies applied to all residential areas. The reference scenarios are the results of the "No mitigation" strategy for each scenario which results in $0 \%$ risk reduction (e.g. for the 2030 low scenario, the reference is the no mitigation strategy resulting in $0 \%$ risk reduction).

be expected. The projected increase in risk due to land-use and climate change (without adaptation) is not entirely compensated by the mitigation strategies; however, the strategies would decrease the risk from $€ 61$ and $€ 89$ million per year for the 2030 low and 2030 high scenarios, respectively, to about $€ 43$ and $€ 53$ million per year when the wet\&dryproofing strategy is implemented. The relative risk-reduction capacity of each measure, compared with no mitigation, can be seen in Fig. 7. The relative reduction in risk ranges from $10 \%$ for the wet-proofing strategy, when applied to the 2000 scenario, up to $40 \%$ for the wet\&dry-proofing strategy in the 2030 high scenario. 


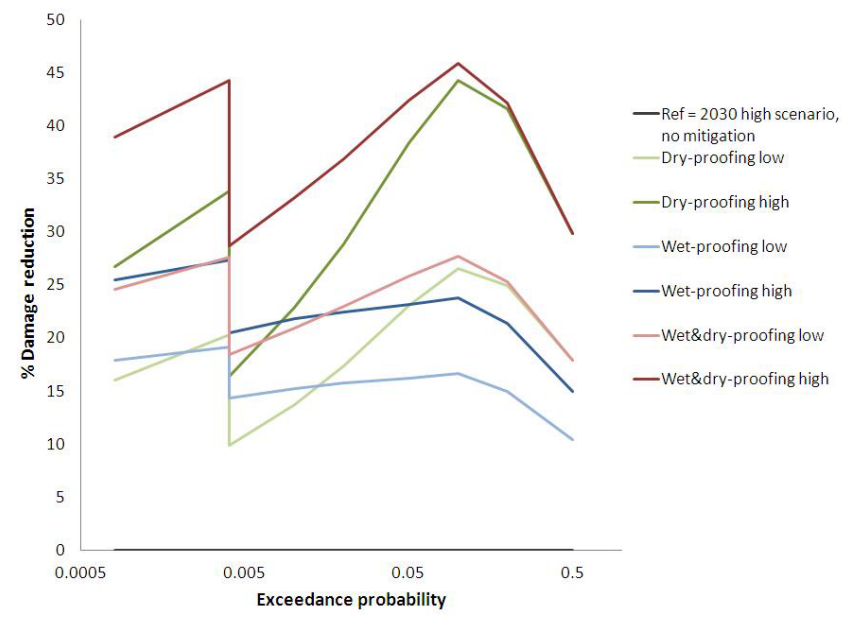

Fig. 8. Damage reduction results (\%) of different mitigation strategies applied to all residential buildings, for different exceedance probabilities and for the 2030 high scenario with mitigation compared with the 2030 high scenario without mitigation (the "no mitigation" strategy). Note that the exceedance probabilities are shown on a logarithmic scale.

Figure 8 shows an example of the relative damage reduction, in percentage terms, induced by the different mitigation strategies. This figure represents the damage reduction induced by the mitigation strategies for the 2030 high scenario. The results of Fig. 8 are similar to the results for the other scenarios (2000 scenario and 2030 low scenario). The effectiveness of the mitigation strategies is up to about $45 \%$ for the wet\&dry-proofing strategy for floods of return periods of $10 \mathrm{yr}$ (i.e. floods with exceedance probabilities of 0.1 ). For floods of a return period of $2 \mathrm{yr}$ (i.e. 0.5 exceedance probability) and for floods of return periods of $20 \mathrm{yr}$ to $250 \mathrm{yr}$ (i.e. 0.05 to 0.004 exceedance probability), the effectiveness of the strategies is lower, down to about $30 \%$ for the wet\&dry-proofing strategy. However, for floods of return periods higher than $251 \mathrm{yr}$ (i.e. 0.004 exceedance probability or lower, dike failure), the effectiveness of the strategies is between about $40 \%$ and $45 \%$. Figure 7 shows that the dryproofing strategy would have similar results in reducing the risk to the wet\&dry-proofing strategy. Figure 8 shows, however, that the strategies lead to different damage reductions for different return periods. For floods with a return period of $10 \mathrm{yr}$ or lower (i.e. exceedance probability higher than 0.1 ), the dry-proofing and wet\&dry-proofing strategies result in similar damage reduction. For lower exceedance probabilities, the dry-proofing strategy is less effective than the wet\&dry-proofing strategy. This divergence is linked to the higher inundation depths that can be found during floods of lower probabilities, since the dry-proofing strategy is no longer effective during floods in excess of $1 \mathrm{~m}$ depth.

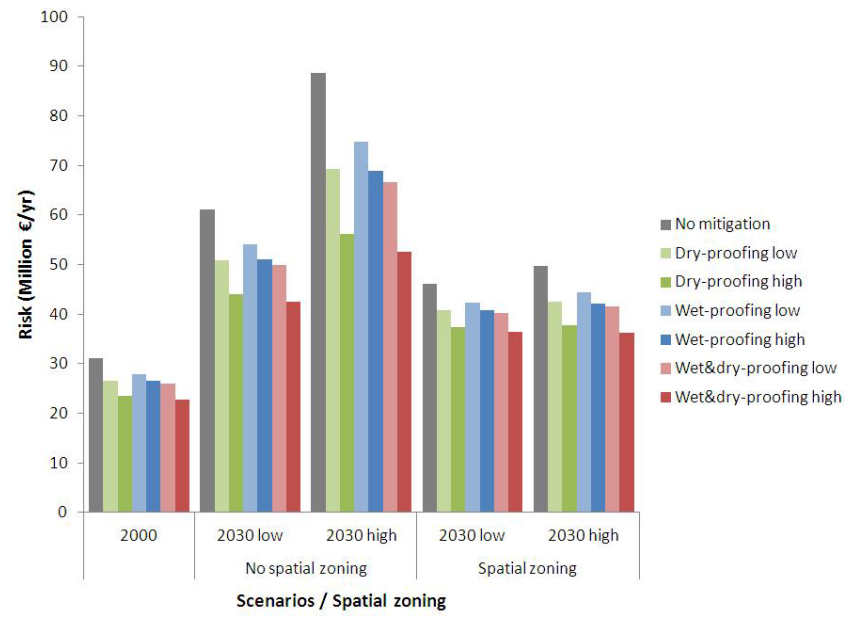

Fig. 9. Risk results (expressed in terms of EAD) for low and high climate and land-use scenarios (in million euros per year), for the different adaptation strategies (i.e. spatial zoning and mitigation measures) applied to all residential areas.

\subsubsection{Mitigation factors applied to new residences only}

Since an implementation of the strategies to all residential areas is probably not feasible in practice, in a second step the mitigation factors are applied only to all the new residential areas in 2030 , i.e. those areas that are classified as residential in the Land Use Scanner results for 2030, but are not residential in the land-use map of 2000. Accordingly, the risk results are higher and range from $€ 53$ to $€ 70$ million per year, while the risk reduction percentages are lower, ranging from $7 \%$ to $21 \%$, (compared with $10 \%$ to $40 \%$ for all residential areas that are flood-proofed). The damage reduction induced by the mitigation strategies for the 2030 high and 2030 low scenarios are as high as $25 \%$ and $14 \%$, respectively, compared with the same scenario without mitigation. Contrary to the results in Fig. 8, the effectiveness of the strategies is not the highest for the most uncommon floods. Similar to the results in Fig. 8, for floods with an exceedance probability higher than 0.1 , the dry-proofing and wet\&dry-proofing strategies result in similar risk reduction. This similarity decreases for lower exceedance probabilities.

\subsection{Risk-reduction capacity of combined spatial zoning and mitigation measures}

In a final step, the BGR spatial zoning measures are combined with the mitigation measures to assess the potential impact on flood risk of the combination of the different adaptation strategies. Mitigation factors are applied to the land-use maps corrected with the BGR zoning, and to all residential areas.

Figure 9 represents the flood risk estimates, in million euros per year, when the different adaptation strategies are combined. In the 2030 low and high scenarios (no adaptation), 


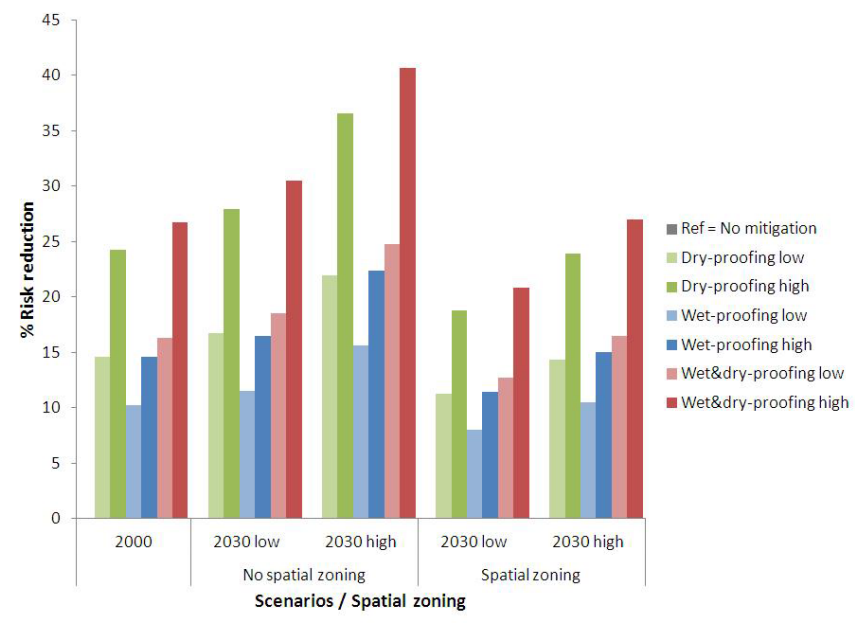

Fig. 10. Risk-reduction capacity (\%) of the different adaptation strategies (i.e. zoning and mitigation measures) applied to all residential areas. The references are the results of the "No mitigation" strategy for each scenario which results in $0 \%$ risk reduction (for instance, for the 2030 high scenario with zoning, the reference is the "No mitigation" strategy resulting in $0 \%$ risk reduction).

the simulated risk is $€ 61$ and $€ 89$ million per year, respectively. The combination of spatial zoning and mitigation measures could decrease the risk in 2030 by about $40 \%$ for the 2030 low scenario (i.e. from $€ 61$ to $€ 36$ million per year), and by almost $60 \%$ for the 2030 high scenario (i.e. from $€ 89$ to $€ 36$ million per year). Figure 10 shows the relative risk-reduction capacity of each mitigation measure, compared with the risk results for each scenario when no mitigation is implemented. For instance, the risk for the 2030 high scenario with zoning and wet\&dry-proofing strategy is compared with the risk for the 2030 high scenario with zoning when no mitigation is implemented. When spatial zoning measures are implemented, the additional relative reduction in risk of the mitigation measures ranges from $8 \%$ to $27 \%$.

\subsection{Geographical distribution of flood risk}

Figure 11a represents the geographical distribution of the risk in million euros per year without adaptation strategies. Figure $11 \mathrm{~b}, \mathrm{c}$, and $\mathrm{d}$ represent the spatial distribution of the riskreduction capacity of the following adaptation strategies: (b) spatial zoning measures alone, (c) dry-proofing strategy alone, and (d) wet-proofing strategy alone. The risk and riskreduction results are aggregated per municipalities in Limburg. The risk results in Fig. 11a are summed per municipality. The risk-reduction results are the averages per municipality.

Figure 11a shows that the risk would be highest in three areas: namely in the northern, upper-central, and southern sections of the region. The upper-central section corresponds to the area around Venlo (35000 inhabitants), and the southern section corresponds to the area around Maastricht
(120 000 inhabitants). In these areas, as well as in the northern section, the high risk results are linked to both the high inundation depths and the high exposure of assets in these urban areas. However, Ward et al. (2011a) show that, in the northern section of the Meuse in Limburg, Floodscanner tends to overestimate the inundation extent, and therefore the damage. The high risk results in that region may therefore also be partly linked to the overestimation of the Floodscanner model.

According to Fig. 11b, c, and d, there are large geographical differences in the risk-reduction results of the adaptation strategies, which may be interesting to local decision makers. The highest risk-reduction results of spatial zoning are in the southern and central parts of the case-study area. The southern section corresponds to the area around Maastricht. From Fig. $11 \mathrm{c}$ and d, it appears that the highest reductions in risk for both the dry- and the wet-proofing strategies would be realised in the same geographical areas.

\section{Discussion}

\subsection{Comparison with past research}

Our results suggest that flood risk in Limburg may increase by $97 \%$ and $185 \%$ under the 2030 low and high scenarios, respectively, compared with the 2000 scenario. These results are slightly lower than the risk increase results obtained by $\mathrm{Te}$ Linde et al. (2011) on the Rhine, which for the 2030 high scenario (climate $\mathrm{W}+$, land use GE) were up to $230 \%$. However, Te Linde et al. (2011) only assessed risk based on extreme floods with very low probability, and did not take different probabilities into account. Bouwer et al. (2010) estimated risk increases for dike-ring 36 of the Meuse river basin, north of our case-study area. When asset value increases are not included in the calculations, the authors projected increases in risk between 2000 and the future of $50 \%$ and $334 \%$ (for low and high scenarios, respectively). Hence, the projected risk increase for the future low scenario is similar to that of our study, whilst for the future high scenario it is higher. These differences occur because (a) the time-horizon of the future scenarios used in the study of Bouwer et al. (2010) is 2040, compared with 2030 in our study, and (b) the current and projected land-use patterns differ between the two regions.

\subsection{Effect of spatial zoning measures}

According to the projections of land-use and climate change used in this study, land-use change plays a larger role in the risk increase than does climate change. This is an important finding, since local and regional stakeholders have more control over the distribution of land use (e.g. Janssen et al., 2008) than over the evolution of the climate. Adequate land-use management could significantly decrease the overall risk compared with a situation without these measures. Indeed, when the already ongoing BGR zoning is included 


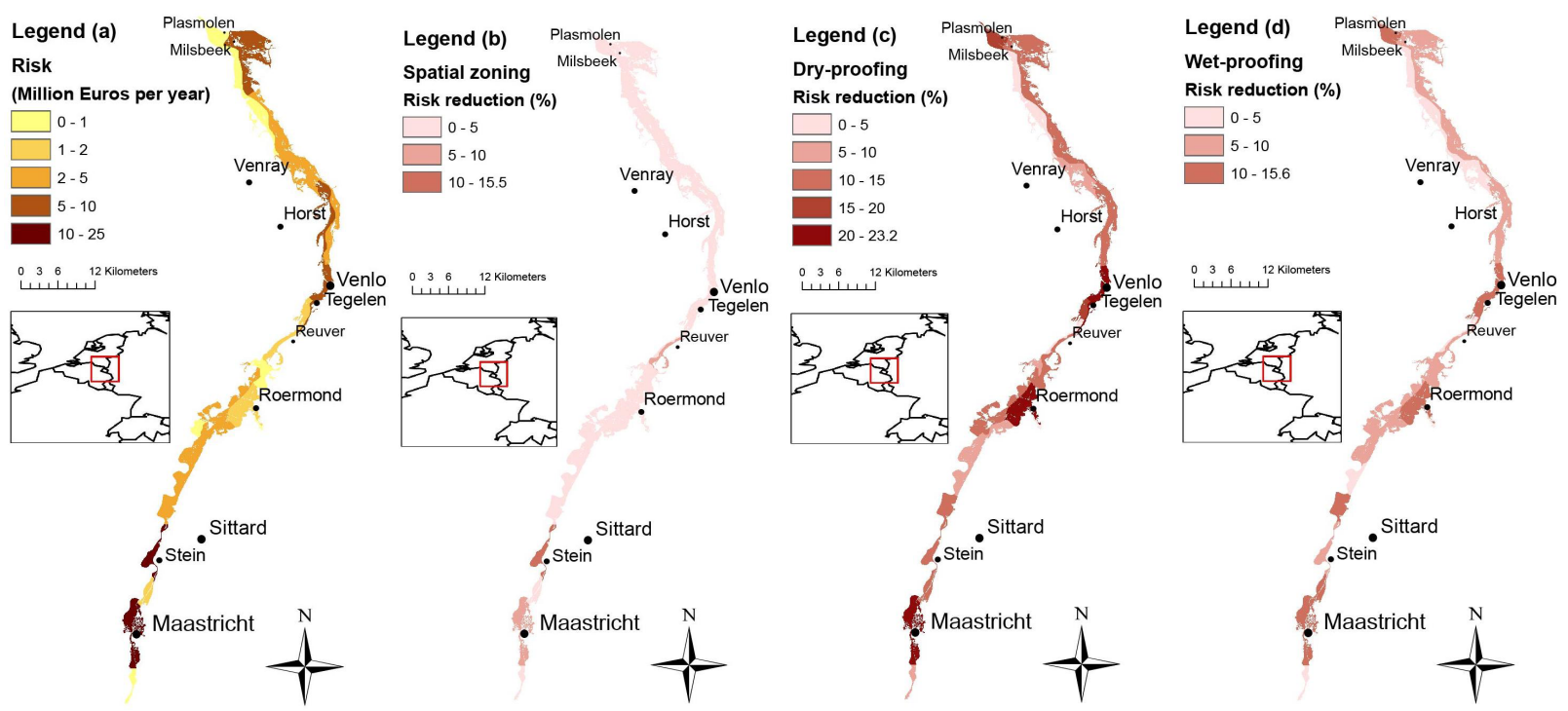

Fig. 11. (a) Risk results per municipalities, without adaptation strategies, in million euros per year, (b) Average risk-reduction results of spatial zoning (\%), (c) Average risk-reduction results of dry-proofing strategy (\%), and (d) Average risk-reduction results of wet-proofing strategy $(\%)$.

in the model, the risk is significantly decreased. However, the simulated risk still increases between the 2000 and the future scenarios, although the relative impact of land-use change becomes much lower when the BGR zoning is included. Other examples of the assessment of existing landuse management programmes in Europe can be found in the literature. For example, Ledoux (2009) and Vinet (2010) describe the French land-use management programme (e.g. Risk Prevention Plans or "Plan de Prévention des Risques"), and show their mixed results after more than $15 \mathrm{yr}$ of implementation, though no quantitative evaluation of the damage and risk reduction has yet been carried out. In the UK, White and Richards (2007) describe the main concerns arising from the land-use management programmes (e.g. PPG25 replaced by PPS25), while Dawson et al. (2011) estimate the potential risk reduction of several adaptation measures, including land-use planning policies.

\subsection{Effectiveness of the mitigation strategies}

The results show that the maximum risk-reduction capacity of the mitigation strategies is up to $21 \%$ and $40 \%$ when implemented only on new buildings in 2030 and in all residential units, respectively. Also, the dry-proofing strategy is more effective at reducing the risk than the wet-proofing strategy. This result differs from the findings of Kreibich et al. (2005) and Kreibich and Thieken (2009), which are based on past floods of the Elbe river in Dresden, Germany. The authors found that during the floods of 2002, and compared with households who had not undertaken mitigation measures, households that had materials available for the undertaking of dry-proofing measures (e.g. private water barriers) did not experience as large a decrease in damage as households that had undertaken wet-proofing measures (e.g. floodadapted use and flood-adapted interior fittings). However, the difference with our results could be related to the fact that the flood of 2002 was an extreme event and private water barriers were overtopped, and had no or little effect (Kreibich et al., 2005).

Additionally, for high probability floods ( $10 \mathrm{yr}$ return periods and less), the dry-proofing strategy has a similar damage reduction capacity to the wet\&dry-proofing strategy. This can be explained by the high mitigation factor chosen for the dry-proofing strategy, which is up to $100 \%$ reduction of the damage for inundation depths lower than $1 \mathrm{~m}$, combined with low inundation depths (e.g. under $1 \mathrm{~m}$ ) which are found during high probability floods. Based on these results, and considering that dry-proofing measures are easier and less expensive to implement than wet-proofing measures (Kreibich and Thieken, 2009), dry-proofing measures seem to be a particularly interesting option to decrease the damage for houses affected by high probability floods. These measures could be implemented prior to, or instead of, implementing wetproofing measures in these areas, although the results also show that wet-proofing measures can also significantly decrease the damage. Further knowledge on the cost-efficiency of dry- and wet-proofing measures would provide an additional ground for decision makers to choose which measures to implement. Such knowledge could have a large impact on the relative attractiveness of the measures.

When the measures are applied to all residential units, the damage reduction capacity of the wet-proofing strategy is the highest for lower probability floods (return period greater than $250 \mathrm{yr}$ ). In areas exposed to low probability floods, the 
widespread implementation of wet-proofing measures (i.e. on both existing and new residences in 2030) would therefore seem particularly suited to decrease the high level of damage that can be expected.

\subsection{Policy implications}

The results of this study show that the already-implemented spatial zoning measures, combined with mitigation measures, could significantly decrease the future risk (see also Aerts et al., 2008). After carrying out preliminary analyses, a workshop was held in Limburg with several regional decision makers to discuss the results and refine the methods for the final analyses. During the workshop, an important remark was made that there are currently no legal means in Limburg, and in the Netherlands, to enforce the undertaking of mitigation measures by households. Further discussion would therefore be needed before the implementation of these measures could be considered. It would also be interesting to assess methods of stimulating households to implement measures. Incentives include measures such as limiting the financial intervention of governments to incite households to take measures prior to floods instead of relying on their government's help after the flood (Kunreuther, 2006); regulating constructions with building codes (Camerer and Kunreuther, 1989; Kunreuther, 2006); providing adequate information to households in flood-prone areas (Camerer and Kunreuther, 1989; Grothmann and Reusswig, 2006; Neuwirth et al., 2000; Sims and Baumann, 1987); and implementing financial incentives such as insurance incentives, where insurers would increase premiums when households live in flood-prone areas and decrease them if households take measures which are effective in reducing the risk (Botzen et al., 2009a b; Camerer and Kunreuther, 1989; Kunreuther, 1996). The existing literature on this subject could serve as a useful starting point for such an analysis.

\subsection{Limitations of the study and future research}

The modelling framework used in this study is relatively simple, but it does allow us to assess the sensitivity of flood risk to climate and land-use change, and to several adaptation options, at a large geographical scale. However, the landuse maps are not very precise at the local level (e.g. street or neighbourhood level) (Schotten et al., 2001; Bouwer et al., 2010; te Linde et al., 2011), which means that the results should not be used at that level. Further research would be needed to increase the precision of the land-use maps, while also including current policy decisions, such as spatial zoning, when using land-use models to simulate future land-use maps (e.g. Aerts et al., 2005). Additional modelling of the risk and damage on a wider scale (e.g. whole-basin scale) could also contribute to the discussion on the adequacy of household mitigation measures, spatial zoning, and the scale at which these adaptation strategies should be used. The spatial zoning measure as applied in this study assumes that although the demand for urban developments will remain, the new buildings will be built outside of the flood-prone area since new buildings within it are not allowed. This assumption can lead to an underestimation of urban development in flood-prone areas in the model. Therefore, additional modelling focused on the allocation of new construction areas under spatial zoning restrictions will have to be conducted to take into account the remaining demand for urban developments.

In addition, research and modelling with methods that allow for more precision on the degree of implementation of the mitigation measures at the town, region, or basin scale could further increase the precision of such a model. Methods to improve these results could include the gathering of data via workshops, interviews, or surveys. Modelling methods such as agent-based modelling could also prove useful in representing the behaviour of households. Finally, the mitigation factors used in this research were derived from the literature on the effectiveness of mitigation measures during past floods. Though the differences in results with Kreibich and Thieken (2009) can be explained by the differences in inundation depths, further research on the subject of the effectiveness of mitigation measures in past and modelled floods could increase the precision of the model and the value of the results for decision makers. Including efficiency aspects of the measures - with the addition of knowledge such as the cost and the difficulty of implementing the measures - could also provide valuable input for decision makers (Bouwer et al., 2012; Jha et al., 2012; Meyer et al., 2012).

\section{Conclusions}

The first aim of this study was to assess the sensitivity of riverine flood risk in the Meuse in Dutch Limburg to changes in land use and climate. In a future without implementation of the adaptation strategies studied in this paper, we projected an approximately two- to three-fold increase in risk (by 2030), with land-use change being the dominant driving factor. This highlights the need to implement adaptation strategies to limit the increase in risk.

This was addressed in the second aim, which was to examine the potential of different adaptation strategies at the regional scale to reduce future flood risk. Our results show that currently ongoing spatial zoning projects can already reduce the increase in risk between 2000 and 2030 by up to $45 \%$. If implemented fully, the relative contributions of landuse and climate change to future flood-risk increase are of a similar order of magnitude.

As well as this strategy, we show that the flood-proofing of houses could further reduce future flood risk, and limit the risk increase that would occur without their implementation. Our results show that the dry-proofing strategy has similar results in reducing the overall risk to the combination 
of dry- and wet-proofing strategies. Since dry-proofing measures are easier and less expensive to implement than wetproofing measures, dry-proofing measures seem particularly interesting to reduce the risk. However, there are large geographical differences in the effectiveness of these mitigation measures. Flood-risk maps, such as those produced in this study, are useful to decision makers for understanding where flood risk hotspots are, and for identifying the strategies most likely to limit the risk in those areas.

This study shows that the strategies examined in this paper can significantly reduce flood risk; this is one of few studies to quantitatively assess the flood-risk reduction capacity of such strategies at the regional scale. However, there appears to be currently few means to enforce or encourage the undertaking of mitigation measures by households. Several methods may be used by governments and insurers to motivate households to implement such measures. Further research, providing local, regional, or basin level data on the damage- and risk-reduction capacity of adaptation strategies could therefore provide valuable input for decision makers, and stimulate discussions on the benefits of implementing and encouraging the implementation of these strategies.

Acknowledgements. This research was carried out in the framework of the Dutch knowledge programme Knowledge for Climate $(K v k)$ project HSGR06, as well as in the context of the $\mathrm{KvK}$ project "Climate proof flood risk management", theme 6. Philip Ward is also funded by a grant from the Netherlands Organisation for Scientific Research (NWO: VENI grant). We thank Siebolt Folkertsma and Paul Konings (RWS Limburg) and Jan Molleman (Province of Limburg) for providing data sets; and Rinus Potter (Waterschap Roer en Overmaas) and Hendrik Buiteveld (RWS Waterdienst) for participating in discussions on the methods used. We also thank two anonymous reviewers for their useful comments on an earlier version of the manuscript.

Edited by: H. Kreibich

Reviewed by: two anonymous referees

\section{References}

ABI: Assessment of the cost and effect on future claims of installing flood damage resistant measures. Association of British Insurers, London, 2003.

Aerts, J. C. J. H. and Botzen, W. J. W.: Climate change impacts on pricing long-term flood insurance: A comprehensive study for the Netherlands, Global Environ. Change, 21, 1045-1060, 2011.

Aerts, J. C. J. H. and Droogers, P.: Climate Change in contrasting river basins, Adaptation strategies for water for food and water for the environment, CABI, Wallingfort, 2004.

Aerts, J. C. J. H., Herwijnen, M., Janssen, R., and Stewart, T. J.: Evaluating spatial design techniques for solving land-use allocation problems, J. Environ. Plan. Man., 48, 121-142, 2005.

Aerts, J. C. J. H., Renssen, H., Ward, P. J., De Moel, H., Odada, E., Bouwer, L. M., and Goosse, H.: Sensitivity of global river dis- charges under Holocene and future climate conditions, Geophys. Res. Lett., 33, L19401, doi:10.1029/2006GL027493, 2006.

Aerts, J. C. J. H., Botzen, W. J., Van der Veen, A., Krykrow, J., and Werners, S.: Portfolio management for developing flood protection measures, Ecol. Soc. 12, 30, available at: http://www. ecologyandsociety.org/vol12/iss2/art30/ (last access: 6 November 2012), 2008.

Barredo, J. I.: Normalised flood losses in Europe: 1970-2006, Nat. Hazards Earth Syst. Sci., 9, 97-104, doi:10.5194/nhess-9-972009, 2009.

Bates, P. D. and De Roo, A. P. J.: A simple raster-based model for flood inundation simulation, J. Hydrol., 236, 54-77, 2000.

Booij, M. J.: Impact of climate change on river flooding assessed with different spatial model resolutions, J. Hydrol., 303, 176198, 2005.

Botzen, W. J. W, Aerts, J. C. J. H., and Van den Bergh, J. C. J. M.: Dependence of flood risk perceptions on socioeconomic and objective risk factors, Water Resour. Res., 45, W10440, doi:10.1029/2009WR007743, 2009a.

Botzen, W. J. W., Aerts, J. C. J. H., and Van den Bergh, J. C. J. M.: Willingness of homeowners to mitigate climate risk through insurance, Ecol. Econ., 68, 2265-2277, 2009b.

Boulet-Desbareau, C., Bessis, B., Moronval, F., and Salagnac, J.: La mitigation en zones inondables, Eléments pour l'élaboration des plans de prévention des risques inondation, Réduire la vulnérabilité des biens existants, Document d'étape, Direction de la Prévention de la Pollution et des Risques (DPPR), Sousdirection de la Prévention des risques majeurs, Ministère de l'Ecologie et du Développement Durable (MEDD), Paris, 2005.

Bouwer, L. M., Vermaat, J., and Aerts, J. C. J. H.: Winter atmospheric circulation and river discharge in northwestern Europe, Geophys. Res. Lett., 33, L06403, doi:10.1029/2005GL025548, 2006.

Bouwer, L. M., Bubeck, P., Wagtendonk, A. J., and Aerts, J. C. J. H.: Inundation scenarios for flood damage evaluation in polder areas, Nat. Hazards Earth Syst. Sci., 9, 1995-2007, doi:10.5194/nhess9-1995-2009, 2009.

Bouwer, L. M., Bubeck, P., and Aerts, J. C. J. H.: Changes in future flood risk due to climate and development in a Dutch polder area, Global Environ. Change, 20, 463-471, 2010.

Bouwer, L. M., Poussin, J., Papyrakis, E., Daniel, V. E., Pfurtscheller, C., Thieken, A. H., and Aerts, J. C. J. H.: Methodology report on costs of mitigation, Costs of Natural Hazards, CONHAZ report, WP4 Final Report, CONHAZ consortium, available at: http://conhaz.org/ project/cost-assessment-work-packages/wp1-8-final-reports/ CONHAZ\%20REPORT\%20WP04_2.pdf/view (last access: 6 November 2012), 2012.

Bubeck, P., de Moel, H., Bouwer, L. M., and Aerts, J. C. J. H.: How reliable are projections of future flood damage?, Nat. Hazards Earth Syst. Sci., 11, 3293-3306, doi:10.5194/nhess-11-32932011, 2011.

Burby, R., Deyle, R., Godschalk, D., and Olshansky, R.: Creating Hazard Resilient Communities through Land-Use Planning, Nat. Hazards Rev., 1, 99-106, 2000.

Camerer, C. F. and Kunreuther, H. C.: Decision processes for low probability events: Policy implications, J. Policy Anal. Manag., 8, 565-592, 1989. 
Crichton, D.: The risk triangle, in: Natural Disaster Management, edited by: Ingleton, J., Tudor Rose, London, 102-103, 1999.

Crichton, D.: Role of insurance in reducing flood risk, The Geneva Papers, 33, 117-132, 2008.

Dawson, R. J., Ball, T., Werritty, J., Werritty, A., Hall, J. W., and Roche, N.: Assessing the effectiveness of non-structural flood management measures in the Thames Estuary under conditions of socio-economic and environmental change, Global Environ. Change, 21, 628-646, 2011.

De Moel, H., Aerts, J. C. J. H., and Koomen, E.: Development of flood exposure in the Netherlands during the 20th and 21st century, Global Environ. Change, 21, 620-627, 2011.

De Wit, M.: Gouttes de pluies, flux de Meuse, Une gestion transnationale de l'eau par temps sec et humide, Veen Magazines, Diemen, 2008.

De Wit, M., Warmerdam, P., Torfs, P., Uijlenhout, R., Roulin, E., Cheymol, A., Van Deursen, W., Van Walsum, P., Ververs, M., Kwadijk, J., and Buiteveld, H.: Effect of climate change on the hydrology of the river Meuse, Dutch National Research Programme on Global Air Pollution and Climate Change, Report number 410.200.090, RIVM, Bilthoven, 2001.

De Wit, M. J. M., Van den Hurk, B., Warmerdam, P. M. M., Torfs, P. J. J. F., Roulin, E., and Van Deursen, W. P. A.: Impact of Climate Change on low-flows in the river Meuse, Climatic Change, 82, 351-372, 2006.

De Wit, M. J. M., Peeters, H., Gastaud, P. H., Dewil, P., Maeghe, K., and Baumgart, J.: Floods in the Meuse basin: Event descriptions and an international view on ongoing measure, Int. J. River Basin Manage., 5, 279-292, 2007.

Drogue, G., Fournier, M., Bauwens, A., Commeaux, F., De Keizer, O., François, D., Guilmin, E., Degré, A., Detrembleur, S., Dewals, B., Pirotton, M., Pontegnie, D., Sohier, C., and Vaneuville, W.: Analysis of climate change, high-flows and low-flows scenarios on the Meuse basin, AMICE report, WP1 Action 3, AMICE consortium, available at: www.amice-project.eu (last access: 2 May 2012), 2010.

EA (Environment Agency): Damage limitation. How to make your home flood resistant. CIRIA, Environment Agency, Bristol, 2003.

Ernst, J., Dewals, B., Detrembleur, S., Archambeau, P., Erpicum, S., and Pirotton, M.: Micro-scale flood risk analysis based on detailed 2-D hydraulic modelling and high resolution geographic data, Nat Hazards, 55, 181-209, 2010.

Grothmann, T. and Reusswig, F.: People at risk of flooding: why some residents take precautionary action while others do not, Nat Hazards, 38, 101-120, 2006.

Grossi, P. and Kunreuther, H.: Catastrophe Modelling: A New Approach to Managing Risk, Springer Science, Business Media Inc., New York, 2005.

ICPR: Non Structural Flood Plain Management: Measures and Their Effectiveness, International Commission for the Protection of the Rhine (ICPR), Koblenz, 2002.

IPCC: Special report on emissions scenarios, in: Intergovernmental Panel on Climate Change, edited by: Nakicenovic, N. and Swart, R., Geneva, 2000.

IPCC: Climate change: the physical science basis, in: Contribution of Working Group I to the Fourth Assessment Report of the Intergovernmental Panel on Climate Change, edited by: Solomon, S., Qin, D., Manning, M., Chen, Z., Marquis, M., Averyt, K. B.,
Tignor, M., and Miller, H. L., Cambridge University Press, Cambridge, New York, 2007.

IPCC: Managing the Risks of Extreme Events and Disasters to Advance Climate Change Adaptation, A Special Report of Working Groups I and II of the Intergovernmental Panel on Climate Change, Cambridge University Press, Cambridge, New York, 2012.

Jacquet, P., Raymond, M., Martir, O., and Rouas, G.: Modélisation des crues de la MEUSE : Genèse des crues et des inondations: Compréhension actuelle des phénomènes physiques (1ère partie) $=$ MEUSE river flood modelling, Houille blanche, 6, 94-103, 2003.

Janssen, R., Herwijnen, M. V., Stewart, T., and Aerts, J. C. J. H.: Multiobjective decision support for land use planning, Environ. Plann. B, 35, 740-756, 2008.

Jha, A. K., Bloch, R., and Lamond, J.: Cities and Flooding, A guide to Integrated Urban Flood Risk Management for the 21st Century, The World Bank, Washington DC, available at: www.gfdrr. org/gfdrr/urbanfloods (last access: 6 November 2012), 2012.

Klijn, F., Baan, P. J. A., De Bruijn, K. M., and Kwadijk, J.: Overstromingsrisico's in Nederland in een veranderend klimaat, Verwachtingen, schattingen en berekeningen voor het project Nederland Later, Report number Q4290, WL Delft Hydraulics, Delft, 2007.

Kreibich, H. and Thieken, A. H.: Coping with floods in the city of Dresden, Germany, Nat Hazards, 51, 423-436, 2009.

Kreibich, H., Thieken, A. H., Petrow, Th., Müller, M., and Merz, B.: Flood loss reduction of private households due to building precautionary measures - lessons learned from the Elbe flood in August 2002, Nat. Hazards Earth Syst. Sci., 5, 117-126, doi:10.5194/nhess-5-117-2005, 2005.

Kreibich, H., Christenberger, S., and Schwarze, R.: Economic motivation of households to undertake private precautionary measures against floods, Nat. Hazards Earth Syst. Sci., 11, 309-321, doi:10.5194/nhess-11-309-2011, 2011.

Kreibich, H., Christenberger, S., and Schwarze, R.: Corrigendum to "Economic motivation of households to undertake private precautionary measures against floods" published in Nat. Hazards Earth Syst. Sci., 11, 309-321, 2011, Nat. Hazards Earth Syst. Sci., 12, 391-392, doi:10.5194/nhess-12-391-2012, 2012.

Kunreuther, H. C.: Mitigating Disaster Losses through Insurances, J. Risk. Uncertainty, 12, 171-187, 1996.

Kunreuther, H. C.: Disaster mitigation and insurance: Learning from Katrina, Ann. Am. Acad. Polit., 604, 208-227, 2006.

Leander, R., Buishand, T. A., Van den Hurk, B. J. J. M., and De Wit, M. J. M.: Estimated changes in flood quantiles of the river Meuse from resampling of regional climate model output, J. Hydrol., 351, 331-343, 2008.

Ledoux, B.: Etat de l'art des recherché sur certaines mesures nonstructurelles de gestion du risque inondation (PPR et système Catnat), Cemagref. Ministère de l'Ecologie, de l'Energie, du Développement Durable et de la Mer (MEEDDM), Paris, 2009.

Loche, G.: Inondations catastrophiques à Charleville-Mézières, Pourquoi?, Bulletin de la Société d'histoire naturelle des Ardennes, 84, 52-64, 1994.

Loonen, W. and Koomen, E.: Calibration and validation of the Land Use Scanner allocation algorithms, Netherlands Environmental Assessment Agency (PBL), 2009. 
Maaskant, B., Jonkman, S. N., and Bouwer, L. M.: Future risk of flooding: an analysis of changes in potential loss of life in South Holland (The Netherlands), Environ. Sci. Policy, 12, 157-169, 2009.

Merz, B., Kreibich, H., Schwarze, R., and Thieken, A.: Review article "Assessment of economic flood damage", Nat. Hazards Earth Syst. Sci., 10, 1697-1724, doi:10.5194/nhess-10-16972010, 2010.

Meyer, V., Becker, N., Markantonis, V., Schwarze, R., Aerts, J. C. J. H., Van den Bergh, J. C. J. M., Bouwer, L. M., Bubeck, P., Ciavola, P., Daniel, V., Genovese, E., Green, C., Hallegatte, S., Kreibich, H., Lequeux, Q., Lochner, B., Logar, I., Papyrakis, E., Pfurtscheller, C., Poussin, J., Przyluski, V., Thieken, A. H., Thompson, P., and Viavattene, C.: Costs of Natural Hazards - A Synthesis, Costs of Natural Hazards, Synthesis report, CONHAZ consortium, avalaible at: http://conhaz. org/CONHAZ_WP09_1_Synthesis_Report_final.pdf (last access: 6 November 2012), 2012.

Ministry of Transport, Public Works and Water Management: Flood risks and safety in the Netherlands (Floris), Floris study, full report, Report number DWW-2006-014, Ministry of Transport, Public Works and Water Management, The Hague, 2005.

Munich RE: Geo Natural catastrophes, available at: www. munichre.com/publications/302-06735\{_\}en.pdf (last access: 3 April 2012), 2010.

Neuwirth, K., Dunwoody, S., and Griffin, R. J.: Protection Motivation and Risk Communication, Risk Anal., 20, 721-734, 2000.

Paudel, Y., Aerts, J., and Botzen, W.: Public private catastrophe insurance, Geneva Pap. Risk. Ins., 37, 257-285, 2012.

Pfister, L., Kwadijk, J., Musy, A., Bronstert, A., and Hoffmann, L.: Climate change, land use change and runoff prediction in the Rhine-Meuse River basins, River. Res. Appl., 20, 229-241, 2004.

Poussin, J. K., Aerts, J. C. J. H., and Botzen, W. J. W.: Flood prevention and comparison in the Netherlands, in: Rapport public 2010 : L'eau et son droit, Etudes et documents du Conseil d'Etat, edited by: Cassin, R., Sauve, J. M., and Robineau, Y., La Documentation Francaise, Paris, 525-536, 2010.

Poussin, J. K., Ward, P. J., Bubeck, P., Gaslikova, L., Schwerzmann, A., Raible, C. C.: Flood Risk Modelling, in: Climate Adaptation and Flood Risk in Coastal Cities, Earthscan, London, New York, 93-121, 2012.

Priestnall, G., Jaafar, J., and Duncan, A.: Extracting urban features from LiDAR-derived digital surface models, Comput. Environ. Urban, 24, 65-78, 2000.

Schotten, K., Goetgeluk, R., Hilferink, M., Rietveld, P., and Scholten, H.: Residential construction, land use and the environment, Simulations for the Netherlands using a GIS-based land use model, Environ. Model. Assess., 6, 133-143, 2001.

Sims, J. H. and Baumann, D. D.: The Adoption of Residential Flood Mitigation Measures: What Price Success?, Econ. Geogr., 63, 259-272, 1987.

Te Linde, A. H., Aerts, J. C. J. H., Bakker, A. M. R., and Kwadijk, J. C. J.: Simulating low probability peak discharges for the Rhine basin using resampled climate modeling data, Water Resour. Res., 46, W03512, doi:10.1029/2009WR0077072010, 2010.

Te Linde, A. H., Bubeck, P., Dekkers, J. E. C., De Moel, H., and Aerts, J. C. J. H.: Future flood risk estimates along the river Rhine, Nat. Hazards Earth Syst. Sci., 11, 459-473, doi:10.5194/nhess-11-459-2011, 2011.
Thurston, N., Finlinson, B., Breakspear, R., Williams, N., Shaw, J., and Chatterton, J.: Developing the evidence base for flood resistance and resilience. R\&D Summary Report, Joint Defra/EA Flood and Coastal Erosion, London, 2008.

Tu, M.: Assessment of the effects of climate variability and land use change on the hydrology of the Meuse river basin, Ph.D. Thesis, VU University Amsterdam, Amsterdam, UNESCOIHE, Delft, 2006.

UNISDR: GAR, 2011. Global Assessment Report on Disaster Risk Reduction. Revealing Risk, Redefining Development. United Nations International Strategy for Disaster Reduction Secretariat, Geneva, 2011.

Van den Hurk, B., Klein Tank, A., Lenderink, G., Van Ulden, A., Van Oldenborgh, G., Katsman, C., Van den Brink, H., Keller, F., Bessembinder, J., Burgers, G., Komen, G., Hazeleger, W., and Drijfhout, S.: KNMI Climate Change Scenarios 2006 for the Netherlands, Report number WR 2006-01, KNMI, De Bilt, 2006.

Van der Meulen, M. J., Rijnveld, M., Gerrits, L. M., Joziasse, J., Van Heijst, M. W. I. M., and Gruijters, S. H. H. L.: Handling Sediments in Dutch River Management: The Planning Stage of the Maaswerken River Widening Project, J. Soils Sediments, 6, 163-172, 2006.

Van der Sande, C. J., De Jong, S. M., and De Roo, A. P. J.: A segmentation and classification approach of IKONOS-2 imagery for land cover mapping to assist flood risk and flood damage assessment, Int. J. Appl. Earth. Obs., 4, 217-229, 2003.

Van Meijgaard, E. and Jilderda, R.: The Meuse flood in January 1995, Weather, 51, 39-45, 1996.

Van Pelt, S. C., Kabat, P., Ter Maat, H. W., Van den Hurk, B. J. J. M., and Weerts, A. H.: Discharge simulations performed with a hydrological model using bias corrected regional climate model input, Hydrol. Earth Syst. Sci., 13, 2387-2397, doi:10.5194/hess13-2387-2009, 2009.

Vinet, F.: Le risque inondation Diagnostic et gestion, TEC \& DOC, Lavoisier, Paris, 2010.

Vis, M., Klijn, F., De Bruijn, K. M., and Van Buuren, M.: Resilience strategies for flood risk management in the Netherlands, Int. J. River Basin Manage., 1, 33-40, 2003.

Ward, P. J.: River Meuse suspended sediment yield: a new estimate and past estimates revisited, Neth. J. Geosci., 87, 189-193, 2008.

Ward, P. J., Aerts, J. C. J. H., De Moel, H., and Renssen, H.: Verification of a coupled climate-hydrological model against Holocene palaeohydrological records, Global Planet. Change, 57, 283300, 2007.

Ward, P. J., Renssen, H., Aerts, J. C. J. H., Van Balen, R. T., and Vandenberghe, J.: Strong increases in flood frequency and discharge of the River Meuse over the late Holocene: impacts of long-term anthropogenic land use change and climate variability, Hydrol. Earth Syst. Sci., 12, 159-175, doi:10.5194/hess-12-1592008, 2008.

Ward, P. J., Van Balen, R. T., Verstraeten, G., Renssen, H., and Vandenberghe, J.: The impact of land use and climate change on late Holocene and future suspended sediment yield of the Meuse catchment, Geomorphology, 103, 389-400, 2009.

Ward, P. J., De Moel, H., and Aerts, J. C. J. H.: How are flood risk estimates affected by the choice of return-periods?, Nat. Hazards Earth Syst. Sci., 11, 3181-3195, doi:10.5194/nhess-113181-2011, 2011a. 
Ward, P. J., Renssen, H., Aerts, J. C. J. H., and Verburg, P. H.: Sensitivity of discharge and flood frequency to 21 st Century and late Holocene changes in climate and land use (River Meuse, northwest Europe), Climatic Change, 106, 179-202, 2011 b.

Ward, P. J., Pauw, W. P., Van Buuren, M. W., and Marfai, M. A.: Governance of flood risk management in a time of climate change: the cases of Jakarta and Rotterdam, Environ. Polit., online first, doi:10.1080/09644016.2012.683155, 2012.
White, I. and Richards, J.: Planning Policy and Flood Risk: The Translation of National Guidance into Local Policy, Plan. Pract. Res., 22, 513-534, 2007.

Wind, H. G., Nierop, T. M., De Blois, C. J., and De Kok, J. L.: Analysis of flood damages from the 1993 and 1995 Meuse floods, Water Resour. Res., 35, 3459-3465, 1999. 